\title{
Lactobacillus paracollinoides sp. nov., isolated from brewery environments
}

\author{
Correspondence \\ Koji Suzuki \\ koji.suzuki@asahibeer.co.jp
}

\author{
Koji Suzuki, ${ }^{1}$ Wataru Funahashi, ${ }^{2}$ Masahiro Koyanagi ${ }^{1}$ \\ and Hiroshi Yamashita ${ }^{1}$ \\ Analytical Technology Laboratory ${ }^{1}$ and Brewing Research \& Development Laboratory ${ }^{2}$, Asahi \\ Breweries Ltd, 1-2 Midori 1-chome, Moriya-shi, Ibaraki, 302-0106, Japan
}

\begin{abstract}
Three novel strains isolated from brewery environments are described. These strains were Gram-positive, facultatively anaerobic, heterofermentative rods that did not exhibit catalase activity. Phylogenetic analysis based on 16S rRNA gene sequence similarity showed that these strains belong to the genus Lactobacillus and are most closely related to Lactobacillus collinoides (approximately $99 \%$ similarity). The novel strains could be differentiated from $L$. collinoides on the basis of DNA-DNA relatedness, differences in beer-spoilage ability and the inability to utilize D-fructose. These isolates represent a novel species, for which the name Lactobacillus paracollinoides sp. nov. is proposed. The type strain is $\mathrm{LA}^{\top}\left(=\mathrm{DSM} 15502^{\top}=\mathrm{JCM} 11969^{\top}\right)$.
\end{abstract}

Although the majority of bacteria are incapable of growing in beer, a limited number of species of lactobacilli exhibits strong beer-spoilage ability (Back, 1981). Lactobacillus brevis is known to be the most prevalent beer-spoilage species (Back et al., 1988; Back, 1994a). Three brewery isolates, $\mathrm{LA} 2^{\mathrm{T}}$, LA3 and LA4, that possess strong beer-spoilage ability have been reported previously (Funahashi et al., 1998). Since these three strains showed identical ribotypes and morphological features, the isolates were indistinguishable at the strain level. Coupled with the fact that these three strains were isolated from one brewery, they may well be considered to be identical. The representative strain, $\mathrm{LA} 2^{\mathrm{T}}$, did not show sufficient DNA-DNA relatedness to be classified as any of the validly published Lactobacillus species, although it was most closely related to Lactobacillus collinoides JCM $1123^{\mathrm{T}}$ on the basis of 16S rRNA gene sequence comparisons (Funahashi et al., 1998). L. collinoides strains are not generally considered to be beer-spoilage bacteria (Back, 1994b; Carr \& Davies, 1972, 1974), but LA2 ${ }^{\mathrm{T}}$ was able to grow in beer.

Recently, strains LA7 and LA8 have been isolated from different breweries in Japan. These strains also exhibited strong beer-spoilage ability. $16 \mathrm{~S}$ rRNA gene sequence analysis indicated that these strains are potentially related to L. collinoides or Lactobacillus sp. LA2 ${ }^{\mathrm{T}}$ at the species level. These findings led us to characterize these novel beerspoilage strains and to investigate their taxonomic relationship with L. collinoides and Lactobacillus sp. LA2 ${ }^{\mathrm{T}}$. Based on

Published online ahead of print on 25 July 2003 as DOI 10.1099/ ijs.0.02722-0.

The DDBJ accession number for the 16S rRNA gene sequence of strain $L A 2^{\top}$ is $E 16651$. these results, a novel species, Lactobacillus paracollinoides sp. nov., is described.

Lactobacillus strains used in this study were grown in MRS broth (Merck) at $25^{\circ} \mathrm{C}$ under anaerobic conditions. Carbohydrate fermentation profiles were determined using the API 50CH system (bioMérieux). API tests were performed in accordance with the manufacturer's instructions. Each strain was examined for morphological features, motility and Gram staining by microscopy. Hydrogen peroxide $(3 \%)$ was used to test for catalase activity. Gas production from glucose was examined using Durham tubes. An F-kit DL-lactic acid (Boehringer Mannheim) was used to determine production of $\mathrm{D}$ - and L-lactic acids. Beer-spoilage ability was determined by inoculating degassed commercial beers $(\mathrm{pH} 4 \cdot 2)$ with each strain at $3 \times 10^{3}$ cells $\mathrm{ml}^{-1}$. The inoculated beers were incubated anaerobically at $25^{\circ} \mathrm{C}$ and examined regularly for visible growth for up to 90 days (Suzuki et al., 2002).

The ribotype of each strain was obtained using a RiboPrinter (Qualicon) in accordance with the manufacturer's instructions, with EcoRI as a restriction enzyme (Bruce et al., 1995; Hubner et al., 1995; Olsen et al., 1991). G+C contents were determined by HPLC as described by Mesbah et al. (1989). Experimental procedures for $16 \mathrm{~S}$ rRNA gene analysis were described previously (Funahashi et al., 1998). Sequences were edited with the DNASIS PRO software package (Hitachi Software Engineering). The CLUSTAL W algorithm (Thompson et al., 1994) provided in DNASIS PRO was used to align sequences and to construct a neighbour-joining tree with 1000 bootstrap iterations. A DNA-DNA hybridization study was carried out as described by De Ley et al. (1970) with some modifications (Escara \& Hutton, 1980; Huß et al., 1983). A model 2600 
spectrophotometer equipped with a model 2527-R thermoprogrammer and plotter (Gilford Instrument Laboratories) was used for determining DNA-DNA relatedness. Renaturation rates were computed with the program TRANSFER.BAS (Jahnke, 1992).

Strains LA2 ${ }^{\mathrm{T}}$, LA7 and LA8 were Gram-positive rods that exhibited no catalase activity. When grown on MRS agar, their colonies were small and non-pigmented. Growth was observed at $15^{\circ} \mathrm{C}$ but not at $45^{\circ} \mathrm{C}$ in MRS broth. All strains produced predominantly D-lactic acid from glucose with a smaller amount of L-lactic acid; the proportion of D-lactic acid ranged between $66 \cdot 5$ and $79 \cdot 1 \%$, depending on the strain. Gas production was observed for each strain. Compared with L. collinoides JCM $1123^{\mathrm{T}}$, the major difference in carbohydrate utilization profiles was the inability of the brewery isolates to ferment D-fructose. The ability to utilize L-arabinose was variable. Except for these differences, carbohydrate utilization by the isolates was identical to that observed in L. collinoides JCM $1123^{\mathrm{T}}$. The DNA G + C content of strain $\mathrm{LA} 2^{\mathrm{T}}$ was $44.8 \mathrm{~mol} \%$, which is within the range for the genus Lactobacillus (32-53 mol\%) (Kandler \& Weiss, 1986).

The beer-spoilage ability of the strains was compared with that of three L. collinoides strains, JCM $1123^{\mathrm{T}}$, ATCC 27610 and ATCC 27611. Strains LA2 ${ }^{\mathrm{T}}$, LA7 and LA8 exhibited strong beer-spoilage ability and formed visual turbidity in beer within 7 days. This degree of beer-spoilage ability is comparable with that of the most serious beer-spoilage bacterium, Lactobacillus brevis (Suzuki et al., 2002). In contrast, none of the three $L$. collinoides strains tested in this study was able to grow in beer, even after 90 days of observation. Thus, strains LA2 ${ }^{\mathrm{T}}$, LA7 and LA8 are distinguishable from $L$. collinoides in terms of beer-spoilage ability.

The 16S rRNA gene sequences of LA7 and LA8 showed approximately $99 \%$ similarity to those of L. collinoides JCM $1123^{\mathrm{T}}$ (DDBJ accession number AB005893) and Lactobacillus sp. LA2 ${ }^{\mathrm{T}}$ (E16651), suggesting that these four strains are closely related. DNA-DNA hybridization data showed that LA7 and LA8 showed $86 \cdot 8$ and $70 \cdot 7 \%$ relatedness, respectively, to $\mathrm{LA}^{\mathrm{T}}{ }^{\mathrm{T}}$. In contrast, DNA similarity between the three brewery isolates and L. collinoides JCM $1123^{\mathrm{T}}$ was relatively low $(46 \cdot 8-57 \cdot 6 \%)$. These results, together with differences in beer-spoilage ability and the ability to utilize D-fructose, show that the three brewery isolates are most likely to be related at the species level and should be regarded as a species distinct from $L$. collinoides. Ribotyping of LA7 and LA8 yielded ribopatterns that were distinct from that of $\mathrm{LA} 2^{\mathrm{T}}$, indicating these three brewery isolates are distinguishable at the strain level. A phylogenetic tree showing the relationship of $\mathrm{LA} 2^{\mathrm{T}}$ with other Lactobacillus species is shown in Fig. 1.

Taken collectively, these results allowed us to assign the brewery isolates described in the present study to a novel

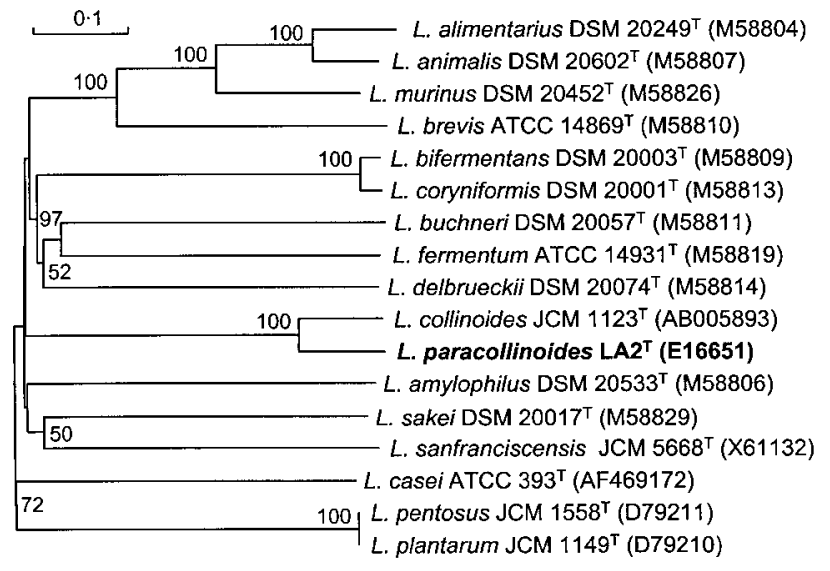

Fig. 1. Phylogenetic tree of Lactobacillus paracollinoides $L A 2^{\top}$ and other Lactobacillus strains derived from 16S rRNA gene sequence data (accession numbers given in parentheses), constructed using the neighbour-joining method. Percentages at nodes were obtained from 1000 bootstrap replications. Bar, $0 \cdot 1$ inferred substitutions per $100 \mathrm{nt}$.

species, for which the name Lactobacillus paracollinoides sp. nov. is proposed.

\section{Description of Lactobacillus paracollinoides sp. nov.}

Lactobacillus paracollinoides (pa.ra.col.li.noi'des. Gr. pref. para beside; N.L. masc. adj. collinoides hill-shaped, referring to the colony form of Lactobacillus collinoides; N.L. masc. adj. paracollinoides beside collinoides, referring to the close relationship to L. collinoides).

Cells are Gram-positive, non-motile, non-spore-forming rods, occurring singly or in short chains. Facultatively anaerobic, catalase-negative and heterofermentative. All strains so far isolated grow at $15^{\circ} \mathrm{C}$, but not at $45^{\circ} \mathrm{C}$. A predominant amount of D-lactic acid, with a smaller amount of L-lactic acid, is produced from glucose. Acid is produced from ribose, D-xylose, D-glucose, maltose and melibiose. Acid production from $\mathrm{L}$-arabinose is variable. No acid is produced from glycerol, erythritol, D-arabinose, Lxylose, adonitol, methyl $\beta$-xyloside, D-fructose, D-mannose, D-sorbose, rhamnose, dulcitol, inositol, mannitol, sorbitol, methyl $\alpha$-D-mannoside, methyl $\alpha$-D-glucoside, $N$-acetyl- $\beta$ glucosamine, amygdalin, arbutin, salicin, cellobiose, lactose, sucrose, trehalose, inulin, melezitose, D-raffinose, starch, glycogen, xylitol, $\beta$-gentiobiose, D-turanose, D-lyxose, D-tagatose, D- or L-fucose, D- or L-arabitol, gluconate or 2- or 5-ketogluconate.

The DNA G + C content of the type strain, strain LA2 ${ }^{\mathrm{T}}$ $\left(=\mathrm{DSM} 15502^{\mathrm{T}}=\mathrm{JCM} 11969^{\mathrm{T}}\right)$, is $44 \cdot 8 \mathrm{~mol} \%$. Isolated from brewery environments. All the strains presently isolated exhibit strong beer-spoilage ability. 


\section{References}

Back, W. (1981). Bierschaedliche Bakterien. Monatsschr Brauerei 34, 267-276.

Back, W. (1994a). Secondary contaminations in the filling area. Brauwelt Int 4, 326-333.

Back, W. (1994b). Einteilung der bierschaedlichen Bakterien. In Farbatlas und Handbuch der Getraenkebiologie, vol. 1, pp. 62-67. Edited by W. Back. Nürnberg: Verlag Hans Karl.

Back, W., Breu, S. \& Weigand, C. (1988). Infektionsursachen im Jahre 1987. Brauwelt 31/32, 1358-1362.

Bruce, J. L., Hubner, R. J., Cole, E. M., McDowell, C. I. \& Webster, J. A. (1995). Sets of EcoRI fragments containing ribosomal RNA sequences are conserved among different strains of Listeria monocytogenes. Proc Natl Acad Sci U S A 92, 5229-5233.

Carr, J. G. \& Davies, P. A. (1972). The ecology and classification of strains of Lactobacillus collinoides nov. spec.: a bacterium commonly found in fermenting apple juice. J Appl Bacteriol 35, 463-471.

Carr, J. G. \& Davies, P. A. (1974). Designation of a type strain for Lactobacillus collinoides. J Appl Bacteriol 37, 471-472.

De Ley, J., Cattoir, H. \& Reynaerts, A. (1970). The quantitative measurement of DNA hybridization from renaturation rates. Eur $J$ Biochem 12, 143-153.

Escara, J. F. \& Hutton, J. R. (1980). Thermal stability and renaturation of DNA in dimethyl sulfoxide solutions: acceleration of the renaturation rate. Biopolymers 19, 1315-1327.

Funahashi, W., Suzuki, K., Ohtake, Y. \& Yamashita, H. (1998). Two novel beer-spoilage Lactobacillus species isolated from breweries. $J \mathrm{Am}$ Soc Brew Chem 56, 64-69.
Hubner, R. J., Cole, E. M., Bruce, J. L., McDowell, C. I. \& Webster, J. A. (1995). Types of Listeria monocytogenes predicted by the positions of EcoRI cleavage sites relative to ribosomal RNA sequences. Proc Natl Acad Sci U S A 92, 5234-5238.

Huß, V. A. R., Festl, H. \& Schleifer, K. H. (1983). Studies on the spectrophotometric determination of DNA hybridization from renaturation rates. Syst Appl Microbiol 4, 184-192.

Jahnke, K. D. (1992). Basic computer program for evaluation of spectroscopic DNA renaturation data from GILFORD System 2600 spectrometer on a PC/XT/AT type personal computer. J Microbiol Methods 15, 61-73.

Kandler, O. \& Weiss, N. (1986). Genus Lactobacillus Beijerinck 1901, $212^{\mathrm{AL}}$. In Bergey's Manual of Systematic Bacteriology, vol. 2, pp. 1209-1234. Edited by P. H. A. Sneath, N. S. Mair, M. E. Sharpe \& J. G. Holt. Baltimore: Williams \& Wilkins.

Mesbah, M., Premachandran, U. \& Whitman, W. B. (1989). Precise measurement of the $\mathrm{G}+\mathrm{C}$ content of deoxyribonucleic acid by highperformance liquid chromatography. Int J Syst Bacteriol 39, 159-167. Olsen, I., Johnson, J. L., Moore, L. V. H. \& Moore, W. E. C. (1991). Lactobacillus uli sp. nov. and Lactobacillus rimae sp. nov. from the human gingival crevice and emended descriptions of Lactobacillus minutus and Streptococcus parvulus. Int J Syst Bacteriol 41, 261-266. Suzuki, K., Sami, M., Kadokura, H., Nakajima, H. \& Kitamoto, K. (2002). Biochemical characterization of horA-independent hop resistance mechanism in Lactobacillus brevis. Int J Food Microbiol 76, 223-230.

Thompson, J. D., Higgins, D. G. \& Gibson, T. J. (1994). CLUSTAL W: improving the sensitivity of progressive multiple sequence alignment through sequence weighting, position-specific gap penalties and weight matrix choice. Nucleic Acids Res 22, 4673-4680. 